\title{
Editorial
}

\section{Estado Laico: uma Agenda para a Saúde Coletiva}

\author{
| Kenneth R. de Camargo Jr. |
}

Em menos de duas semanas, duas jovens mulheres brasileiras chegaram ao noticiário da pior forma possível, ao se tornarem vítimas fatais de abortamentos clandestinos. Jandira Magdalena dos Santos Cruz e Elizângela Barbosa tornaramse a face muito visível de um iceberg que respondeu por 11,4\% das mortes maternas em um inquérito realizado em 2002 (VICTORA et al., 2011), com distribuição desigual, afetando desproporcionalmente mais mulheres pobres e negras.

Quando mais de uma em cada cinco mulheres brasileiras, ao chegar aos quarenta anos de idade, se submeteu a um abortamento provocado (DINIZ; MEDEIROS, 2010), devemos nos questionar por que algo tão frequente e ao mesmo tempo com tal potencial de causar danos segue sendo tabu até mesmo para que seja discutido.

Embora este seja um problema histórico em nosso país, é possível afirmar que essa interdição se acirrou a partir do último ciclo eleitoral, quando o tema do aborto foi injetado no debate político como arma contra quem supostamente defenderia direitos reprodutivos das mulheres, a partir de um discurso religioso conservador e fundamentalista (TREVISAN, 2013). Longe de ser um incidente isolado, a pressão de tais grupos, a partir da atuação disciplinada de uma bancada que se assume como denominacional, interferiu de forma desastrosa com diversas iniciativas de interesse direto ou indireto para a saúde pública.

A interdição do trabalho iniciado em anos anteriores, com a elaboração de cartilha destinada a combater a homofobia, bem como a pressão contra o PL122, que inclui explicitamente a homofobia entre outras formas de discriminação passíveis de punição, é outro exemplo de invasão da esfera republicana pelo sectarismo religioso, também com consequências do ponto de vista da Saúde Coletiva, tendo em vista os impactos negativos, sobre a saúde, de qualquer 
forma de discriminação. No caso da homofobia, essa interferência tem tido repercussōes diretas sobre as respostas à epidemia de HIV/Aids. As evidências epidemiológicas apontam para uma prevalência maior do vírus em populações específicas, em especial trabalhadoras do sexo e jovens HSH (homens que fazem sexo com homens), que deveriam ter políticas preventivas desenhadas especificamente para tais grupos.

Os spots publicitários que deveriam ser veiculados no carnaval de 2012, que faziam referência, ainda que alusiva e indireta, quase velada, aos $\mathrm{HSH}$, foram vetados e deixaram de ser veiculados. No início de 2013, campanha dedicada às prostitutas, elaborada de forma meticulosa e em parceria com as mesmas, foi igualmente vetada, com o argumento de que o objeto das campanhas seria combater a aids e não o preconceito, na contramão de tudo o que se estabeleceu na área ao longo de trinta anos de experiência. Em ambos os casos, mais uma vez a pressão de grupos religiosos no Congresso foi responsável pela interrupção de iniciativas necessárias e bem fundamentadas.

Some-se a esses episódios um número crescente de ataques odiosos aos praticantes de religiões de matriz africana, incluindo violência física contra pessoas e propriedades.

O Estado Laico é uma conquista democrática e a única forma de garantir a liberdade de culto. Ainda que nossa Carta Magna estabeleça que nosso país é uma república laica, a situação de jure está longe de refletir o que de fato ocorre no cotidiano até das instituiçóes que deveriam zelar pela integridade da Constituição. A presença de crucifixos em repartições e tribunais, até mesmo no Supremo Tribunal Federal, demonstra a fragilidade da laicidade do Estado entre nós, em que pese a argumentação tortuosa do Conselho Nacional de Justiça para justificar tal fato (AGUIAR; HILLESHEIM, 2014).

No VI Congresso Brasileiro de Ciências Sociais e Humanas em Saúde, da Abrasco, a laicidade do Estado foi tema de um dos grandes debates. Parecenos que esta é uma questão fundamental para a Saúde Coletiva e mesmo para a cidadania, e devemos portanto procurar incluí-la no debate político sobre os rumos que desejamos para nosso país, para que outras tantas Jandiras e Elizângelas não tenham suas vidas sacrificadas pelas consequências dos preconceitos institucionalizados. 


\section{Referências}

CARVALHO, J.A.; HILlESHEIM, M.C.P. A (In)existência de um Estado Laico no Brasil. Revista Jurídica Democracia, Direito \& Cidadania, v. 5, n. 1, 2014.

DINIZ, D.; MEDEIROS, M. Aborto no Brasil: uma pesquisa domiciliar com técnica de urna. Cien Saude Colet., v. 15, supl. 1, p. 959-966, 2010.

TREVISAN, J. A Frente Parlamentar Evangélica: força política no estado laico brasileiro. Numen, v. 16, n. 1, p. 581-609, 2013.

VICTORA, C.G. et al. Saúde no Brasil 2: Saúde de mães e crianças no Brasil - progressos e desafios. Lancet, v. 377, n. 9.780, p. 1.863-76, 2011. 